\title{
Language Use and Language Attitude among Ukrainian Canadians on the Prairies: An Ethnographic Analysis
}

\author{
Ashley Halko-Addley \\ University of Alberta \\ Natalia Khanenko-Friesen \\ St. Thomas More College, University of Saskatchewan
}

\begin{abstract}
Utilizing an ethnographic perspective and oral history interviews, the article examines Ukrainian language usage among Ukrainian Canadians in Western Canada based on a content analysis of one hundred extended "life histories" recorded in Saskatchewan and Alberta in 2002-03 for the project Sociocultural Change amongst the Ukrainian Canadians on the Prairies: An Oral History. The discussion here focuses on language use and language attitude among the English-speaking participants. This article considers the entire project data but focuses on a preselected sample of ten interviews and examines the correlation between language attitude and community participation. It is asserted that increased community participation brings about changes in the attitudes held by Ukrainian Canadians toward the Ukrainian language in Western Canada. The authors argue that the use of the Ukrainian language in Western Canada unfolds within two domains of cultural practice-habitual and performative, and two functions of language use are identified and discussed-practical/pragmatic and symbolic/ideological.
\end{abstract}

Keywords: Ukrainian Canadians, oral history, Ukrainian language, linguistic anthropology, Western Canada.

$\mathbf{M}$ ore than 125 years have passed since the first Ukrainians set foot in Canada. Since that time up to five immigration waves have arrived in Canada, resulting in the development of a strong ethnic community that claims some 1.36 million Canadians who identify as being of Ukrainian descent (Statistics Canada, "Ethnic and Cultural Origins"). With this diverse immigration history and the wide dispersion of Ukrainians across Canada, it is obvious that a language shift has occurred extensively among Ukrainians in Canada during this time. As in many similar cases of immigrant language use, the Ukrainian language has been actively used within the networks of immigrants proper. Our focus, however, is on how it is being used within the so-called "old" or long-established Ukrainian Canadian community networks in Western Canada. 
As academics, we are intrigued by this question and have addressed it through our professional interactions at the University of Saskatchewan in such contexts as Ukrainian language and culture course discussions, and through our engagements with the Ukrainian community outside of the university. Our observations of language use among "established" Ukrainian Canadians in Saskatoon gave us some preliminary ideas on how the Ukrainian language is being used in the local community. Yet, to put matters into perspective, we felt it would be important to address this question in a more systematic way.

To conduct a cross-analysis of this extended discursive field, we studied the expansive corpus of oral history data previously collected and archived by Natalia Khanenko-Friesen at the Prairie Centre for the study of the Ukrainian heritage (PCUH) at the University of Saskatchewan, at St. Thomas More College. As one of us (Khanenko-Friesen) had earlier conducted an extensive oral history on socio-cultural change among Ukrainian Canadians in the second part of the twentieth century and the other (Ashley HalkoAddley) was seeking an opportunity to gain further experience in field data analysis, we analyzed 120 extensive life history interviews recorded in Alberta and Saskatchewan in 2002-03.

We listened to the interviews conducted in Sociocultural Change Amongst the Ukrainian Canadians on the Prairies: An Oral History (KhanenkoFriesen and Zolner) to test the use of the Ukrainian language, and pursued four lines of query: (a) usage of the Ukrainian language, (b) attitude toward the Ukrainian language, (c) whether the Ukrainian language was passed to the next generation, and (d) if the Ukrainian language was used in community involvement. Our data indicated that the use of the Ukrainian language in Western Canadian prairie settings unfolds within at least two domains of cultural practice, habitual and performative.

\section{HISTORICAL BACKGROUND}

From their earliest settlement in Western Canada, Ukrainian Canadians directed much of their organized effort to language maintenance. In this region, in the early twentieth century, Ukrainians instituted a bilingual school system, with the first bilingual school teachers, before the year 1900 (Marunchak 115). Educational initiatives such as "bursas" (student residences) were built in Saskatoon, Edmonton, and Winnipeg as early as 1916 to maintain community life and sustain Ukrainian language use. In the second half of the twentieth century, Ukrainian language education was introduced in university curricula. The University of Saskatchewan, for example, offered Ukrainian language courses for credit in 1943 (Marunchak 625). 
The adoption of an official policy of multiculturalism in 1971 brought about further possibilities for language retention in the Ukrainian Canadian community. Ukrainians played an instrumental role in the establishment of that policy and effectively lobbied for "federal government support for Ukrainian language instruction centres [supplementary schools]" (Bociurkiw 117). As a result of these efforts, Ukrainian bilingual education was reinstated in Saskatchewan, among other places, in 1979; this allowed the Ukrainian language to be used in the classroom one hundred percent of the time in kindergarten, and fifty percent of the time in grades one through twelve (Lupul 228). The same year, the University of Saskatchewan offered its first course in methods of teaching Ukrainian (Marunchak 747).

Prior to these events, the Ukrainian language, like the Ukrainian settlers themselves, had experienced much prejudice and discrimination (Swyripa). According to the participants in our study, Ukrainian children commonly were not permitted to speak the Ukrainian language at school, adults faced Ukrainian language-based discrimination in the work force, and several Ukrainian family names were anglicized by choice. This discrimination put the Ukrainian language in a position inferior to English, and some speakers of Ukrainian might have chosen to not maintain its use. A linguistic anthropologist, William Foley, notes, "when a language and its associated cultural beliefs and practices are no longer viewed positively by its speakers (no longer carry sufficient social honour), and it is in competition with one that is, it is doomed" (396). How then was a community in Canada whose language was seen by many as inferior able to overcome such prejudice?

Despite negative forces influencing attitudes toward the Ukrainian language in the first part of the twentieth century, the Ukrainian language was maintained by a large number of speakers on the Canadian prairies. Statistical data available shortly after this project was completed, shows that in 2006, 38,165 people in Alberta and 20,355 people in Saskatchewan spoke Ukrainian (Statistics Canada, "2006 Census"). Thus, while the negative treatment of the Ukrainian language throughout the first half of the twentieth century caused some Ukrainian Canadians in Western Canada to stop using their mother tongue, it appears that other Ukrainian Canadians continued to use the Ukrainian language. A century after the first wave of Ukrainians arrived in Canada, in what ways were the long "established" Ukrainian networks in Western Canada using the Ukrainian language?

The interviews documented in Khanenko-Friesen and Zolner's study, took place before two major political events in Ukraine-the Orange Revolution (2004) and the Revolution of Dignity or Euromaidan (2014). As responses to Ukraine's internal political conflicts, both events led to largescale political transformations in other regions of the world. The Orange Revolution overturned the results of a corrupt election in Ukraine, ensuing a re-election of a pro-European president. The Euromaidan led to a similar 
change in the government in Ukraine and was followed by a Russia-backed war in Eastern Ukraine, which is on-going, and the illegal annexation of Crimea by Russia in 2014. These events influenced attitudes toward the Ukrainian language and the Ukrainian culture, not only in Ukraine but in Canada, where Ukrainian Canadians self-mobilized to support Ukraine in its post-Euromaidan struggles. As such, our data, and analysis, should be seen as reflective of recent changes in the Ukrainian Canadian attitude toward the Ukrainian language.

Project respondents represent a group of Ukrainian Canadians who, for the most part, did not come to Canada themselves, but are representatives of second or higher generations of Ukrainian Canadians whose ancestors arrived to Canada between 1891 and the 1960s. Thus, the policy of multiculturalism established in 1971 influenced the evolution of language attitudes in the Ukrainian Canadian community, as reflected in the project interviews.

\section{ORAL History PROJECT}

Data analyzed in this article were based on oral history interviews conducted in 2002 in several communities across Saskatchewan and Alberta and archived at the University of Saskatchewan library at St. Thomas More College as Sociocultural Change amongst the Ukrainian Canadians on the Prairies: An Oral History (Khanenko-Friesen and Zolner). The project documented reflections of Ukrainian Canadians about their personal and biographical experiences within the context of socio-economic change in the latter half of the twentieth century. Four researchers, an anthropologist, a psychologist. and two trained undergraduate students, over a four-month period in the summer of 2002, travelled across the two provinces to speak with individuals who self-identified as Ukrainian Canadians about their life experiences.

The life-history interview was the primary method of data gathering. The life-history interview method of oral historical research emphasizes the interviewee's choice of topics to be discussed (Atkinson). It seeks to record "deep" biographical material, and it focuses on topics of importance to the interviewee, rather than on those of importance to the researcher. A lifehistory interview offers the respondent an opportunity to reflect on his or her life in the form of an extended conversation with a trained researcher. The interviewee chooses the focus for the interview, whereas the interviewer uses the methodological framework to help the interviewee "unpackage" and reflect upon the memories and biographical data that matter the most to the interviewee. The data consisted of extensive valuable narrative material, thus offering an opportunity to researchers to explore 
Ukrainian culture on the Canadian prairies from a variety of perspectives. We focused on the relationship between the subject's identity and the subject's attitude toward the Ukrainian language.

By 2009 , the project database was eventually developed by KhanenkoFriesen, after a field study was completed in 2003. It contains brief descriptions of interviews (including location) and interviewees (including gender, address, and approximate age), partial and full transcripts, and other project documentation. The key themes were developed and interviews were indexed on the basis of key themes. Out of 120 interviews conducted by the project researchers, only 100 were included in the final project database. ${ }^{1}$ Out of 100 interviews in the project database, 39 interviews were conducted with male respondents and 61 interviews were conducted with female respondents. For various reasons, the place of interview was not recorded for 18 respondents. With respect to the interviews with documented locations, 46\% were recorded in rural settings and 54\% were recorded in urban settings. ${ }^{2}$ It should be noted that these locations represent the place in which interviews were conducted, as many respondents participated in interviews in locations other than "home." For example, some interviews took place with respondents living in Ilarion Residence, a Saskatoon nursing home. While Ilarion Residence is situated in an urban centre, some of the respondents had moved to the nursing home from a farm or a town.

\section{METHODOLOGY}

The purpose of the present study was to find out how project respondents used the Ukrainian language throughout their lives (language use), what opinions, beliefs, and feelings respondents developed toward the Ukrainian language (language attitude), and what informed respondents' motivation to use, retain, or learn the Ukrainian language. The above interests were informed by the oral history project data in its entirety. Following an anthropological principle that research questions and research pursuits should be directly informed by ethnographic data rather than the other way around, our first goal was to establish what was of importance to the project

\footnotetext{
1 The project is housed in the University of Saskatchewan library and is searchable under the title "Oral History Project: Ukrainian Canadians on the Prairies."

2 The percentages of rural and urban respondents can be reversed depending on the classification of the city of Humboldt. Humboldt is a city in Saskatchewan that can be classified as urban based on its city status, but the population is small and it only gained city status 2 years before the interviews were conducted, so it could also be argued that it is rural.
} 
respondents with respect to the Ukrainian language. On the basis of this approach, and having listened to all interviews that were available to us, we arrived at the following important observations. First, the project data indicated that the Ukrainian language was important to many respondents. The "importance" or "unimportance" of the Ukrainian language was documented as language attitude. Language attitude ranged from strong to weak, and appeared to be in direct correlation with respondents' community participation. Hence, we concluded that respondents' community participation was an important correlate of language attitude.

The matter of language use within an established ethnic community can be addressed in a variety of ways. Given our disciplinary context we position our discussion here as anthropological, rather than sociological and statistical, and as such we chose to focus on ethnographic detail and in-depth presentation of fewer rather than more life histories. Of the 92 life stories that we consulted, ${ }^{3} 78$ individuals chose to reflect, either at length or minimally, on the role the Ukrainian language played in the participant's life. Thus, given the freedom to explore whatever topics were important to their lives, $84 \%$ of the project respondents brought up (in interview, without being prompted) the topic of the Ukrainian language. Within this corpus, ten interviews stood out as being informative, thoughtful, and well formulated, and represent different levels of language usage, community involvement, and language attitude, as discussed in the present study.

While the sample of ten interviews may appear small from the perspective of anthropology, it provides relevant ethnographic illustration and oral historical evidence of attitudes toward and use of the Ukrainian language among project participants who are "long-established" Ukrainian Canadians, and it supports our claim that for Ukrainian Canadians, use of the Ukrainian language correlates with community participation.

\footnotetext{
${ }^{3}$ Of all project interviews, four of the recordings were damaged or of extremely poor quality and were, thus, excluded from further analysis. Another three interviews were excluded for being conducted with respondents who were not Ukrainian. One interview was excluded where the respondent was a very recent immigrant from post-independent Ukraine and thus did not fit the profile for this study. Notably, while we chose to exclude the latter interview, the respondent was brought to Canada to be a nanny to a long established Ukrainian Canadian family and to speak to the children exclusively in Ukrainian. Three other interviews were removed from the pool as all three were conducted in the Ukrainian language. These interviews were inaccessible to the undergraduate researcher at a time of data analysis, and, since the proposed analysis focuses on English-speaking participants, they were not later included in this count as well. Further, 11 interviews were removed, because the content of the interviews did not cover language.
} 


\section{DISCUSSION}

Table 1 summarizes ethnographic cases according to language use, language attitude, and community involvement. In compliance with the project's ethics protocol, ${ }^{4}$ the names of respondents have been changed and personal data were removed from the discussion and the citations. The data are presented from low to high Ukrainian language use.

Table 1. Language use, language attitude, and community participation among Ukrainian Canadians on the Prairies

\begin{tabular}{|l|l|l|l|l|l|}
\hline Name & Age & $\begin{array}{l}\text { Ukrainian } \\
\text { language } \\
\text { use }\end{array}$ & $\begin{array}{l}\text { Attitude } \\
\text { toward the } \\
\text { Ukrainian } \\
\text { language }\end{array}$ & $\begin{array}{l}\text { Passed the } \\
\text { Ukrainian } \\
\text { language on } \\
\text { to the next } \\
\text { generation }\end{array}$ & $\begin{array}{l}\text { Ukrainian } \\
\text { Community } \\
\text { participation } \\
\text { (current) }\end{array}$ \\
\hline Elizabeth & $30-40$ & None & Neutral & No & No \\
\hline Leo & $30-40$ & None & Negative & No & No \\
\hline Nadia & 20 & Low & Positive & n/a & Yes \\
\hline Mary & 24 & Low & Positive & n/a & Not currently \\
\hline John & 53 & $\begin{array}{l}\text { Low } \text { but } \\
\text { increasing }\end{array}$ & Positive & n/a & Yes \\
\hline Donna & $65-70$ & Low & Positive & No & No \\
\hline Ol'ha & 65 & Medium & Positive & No & No \\
\hline Tania & 43 & High & Positive & Yes & Yes \\
\hline Olena & 50 & High & Positive & n/a & No \\
\hline Orest & 65 & High & Positive & Yes & Yes \\
\hline
\end{tabular}

\footnotetext{
4 This study was conducted according to the ethics regulations of the University of Saskatchewan and approved by the University of Saskatchewan Research Ethics Board in 2002.
} 
UKRAINIAN LANGUAGE USE

To estimate language use and language attitude when listening to the interviews, we noted: (a) overall usage of the Ukrainian language by the participant and (b) the manner in which the English-speaking participant used the Ukrainian language during the interview. Specifically, we looked at how and in which contexts (outside of the interview) the participant used the Ukrainian language and how many of the respondents used it in an active way. The ten interviews described below and depicted in Table 1 illustrate a range of Ukrainian language use, from no usage to low usage to medium usage to high usage. The results are subject to our interpretation of the data.

\section{No Usage of the Ukrainian Language: Elizabeth and Leo}

Elizabeth was in her late thirties or early forties at the time of the interview. A second generation Canadian, Elizabeth is a stay-at-home mother. She was raised in small mining towns in Northern Manitoba, then moved to Ontario, and eventually settled in Saskatoon. The communities that she grew up in were predominantly non-Ukrainian, and as a result she feels that she has lost her culture and has been consumed by the mainstream culture. Both Elizabeth's parents were Ukrainian and they experienced a push to anglicize. Her mother and grandmother were forced to speak English, Ukrainian was not tolerated, and her father felt that being Ukrainian was unacceptable. Due to her parents' attitude, Elizabeth did not grow up speaking Ukrainian. Ukrainian was spoken in her home only when her parents wanted to have a private conversation. Elizabeth took a Ukrainian language class as an adult, and can understand a small amount of Ukrainian when it is spoken to her, but she does not speak Ukrainian. Speaking Ukrainian is not important to Elizabeth and her children do not speak that language. She is not involved in the Ukrainian community and identifies as Canadian more than Ukrainian.

Leo was in his thirties or forties at the time of the interview. He is from east central Alberta. Although Leo's parents spoke Ukrainian, he did not grow up speaking the Ukrainian language at home. He has never been involved with anything in the Ukrainian community beyond attending church. As an adult, Leo decided that he owed it to his grandparents to learn more about his roots. Leo holds a negative view of the Ukrainian community, as he believes that their ancestors worked very hard to become Canadian, and what the Ukrainian community looks like now is not how they wanted it to be. Leo's negative view of the Ukrainian community extends to a negative view of the Ukrainian language. 
Low Usage of the Ukrainian Language: Nadia, Mary, John, and Donna

Nadia, at the time of the interview, was in her early twenties and describes herself as half-Ukrainian. Nadia is involved in Ukrainian dance, she took Ukrainian language classes in high school, and she regularly attends the Ukrainian Catholic Church. Nadia's maternal grandparents came from Ukraine but refused to speak Ukrainian to her mother and suppressed their culture. Her mother felt that she missed out, so she made an effort to revive the Ukrainian identity for her children, because she did not want her children to miss out. Nadia was in French bilingual school, but her younger siblings attended the Ukrainian bilingual program in Saskatoon. Her only formal Ukrainian language classes were in high school and she finished grade twelve level Ukrainian at the Mohyla Summer Immersion Program, but feels that it is hard for her to use Ukrainian in the community. Nadia wishes her family spoke Ukrainian better, and she wishes that she spoke more Ukrainian. She thinks that having a second language is very important and wants her future children to be bilingual, but is unsure if she will teach them Ukrainian or French.

Mary who was, at the time of the interview, in her early twenties, lives in Saskatoon. She was very involved with the Yevshan Ukrainian Folk Ballet for ten years. Mary did not grow up speaking Ukrainian at home. Only her grandmother spoke Ukrainian, but she passed away when Mary was young, so she did not have the opportunity to speak with her. Mary is half-Ukrainian and her father did not hold onto his roots, so she chose to discover them on her own. She learned basic Ukrainian because her Ukrainian dance teacher was learning to speak English and this motivated her to learn Ukrainian so that they could converse and help each other. Mary studied Ukrainian for two years in university. She does not think that she would have been involved in the Ukrainian community had it not been for dance, because getting involved for many other young people was going to events and partying, but she wanted more cultural involvement. Since Mary has stopped dancing she still goes to Ukrainian festivals, but as she is not directly involved with the Ukrainian community, the ties with her Ukrainian identity have loosened.

John, at the time of the interview, was in his fifties. He grew up in a small town in Saskatchewan, which was made up primarily of non-Ukrainians, and he moved to Saskatoon after high school. John grew up speaking Ukrainian, but the home language changed to English when he and his sister started school to encourage them to learn English. His father tried to get them to go to Ukrainian school on Saturday nights to learn Ukrainian, but they were not very interested. When John moved to Saskatoon, he lived at the St. Petro 
Mohyla Institute 5 and became involved with the Ukrainian Orthodox Youth (СУМK). For John, being immersed in Ukrainian was very beneficial. He did not attend church much as an adult. Now John is an author, writing about Ukrainian folktales and pioneer stories, and is slowly learning the language again.

Donna is a grandmother who at the time of the interview was in her midto-late sixties. She grew up in Prince Albert, Saskatchewan, attended university in Saskatoon, and eventually settled in the German community of Humboldt. Donna spoke Ukrainian exclusively until she started school, and took Ukrainian language classes in university. Her husband does not speak Ukrainian, so she did not teach Ukrainian to her children. One of her children saw a lot of Donna's grandmother before the grandmother died and this child can understand some Ukrainian, but Donna's other children cannot. She is upset that her children cannot speak Ukrainian, and that she has lost her ability to speak it. Donna uses the Visnyk Bulletin sent out from Winnipeg to keep up her Ukrainian reading skills. She can read the language well, but her grammar and spoken language are not good now. One of her granddaughters is very involved in Ukrainian dance. Donna wants to send her granddaughter to the Mohyla Institute in Saskatoon to learn Ukrainian.

\section{Medium Usage of the Ukrainian Language: Ol'ha}

Ol'ha is a nurse and was in her mid-sixties at the time of the interview. She grew up on a farm in Saskatchewan, finished high school in Saskatoon, then moved to a small town with a large Ukrainian population. Ol'ha grew up speaking Ukrainian and her school teacher was Ukrainian, but they never had a formal Ukrainian reading program in the school. Ol'ha learned how to read Ukrainian from her children who went to school and took Ukrainian classes. Thus, she can read Ukrainian but cannot write it. Ol'ha's oldest daughter did not speak much English when she went to school because they spent a lot of time speaking Ukrainian at home. This daughter had some problems in school stemming from this. Other children in her daughter's class were more vocal, but she would not ask questions and was shy. Ol'ha and her husband thought if they spoke more English it would help her oldest daughter, so the family switched to using English in the home. Ol'ha's sixth child knew very little Ukrainian. Ol'ha now believes that it is good for people

\footnotetext{
${ }^{5}$ St. Petro Mohyla Institute (Mohyla Institute) is a Ukrainian student residence established in 1916. It was a popular place for the Ukrainian youth to live upon moving to Saskatoon to attend the University of Saskatchewan. Mohyla Institute also offered for many years an intensive summer immersion program to receive high school Ukrainian language credits.
} 
to know a second language. She thinks that it has been good for her to know Ukrainian and has started to teach simple words to the other nurses at the nursing home where she works.

High Usage of Language: Tania, Olena, and Orest

In her forties at the time of the interview, Tania is a mother and a homemaker. She grew up near Toronto, where she was very involved with the Ukrainian community. Tania went to Ukrainian school every Saturday and did not make connections with people outside of the Ukrainian community until she was in university. As a child, Tania said she was forced to go to Ukrainian school, and when she was older, she would skip it. Nonetheless, she taught her daughter how to read and write in Ukrainian and sang Ukrainian folk songs to her. When Tania moved to Saskatoon, she was disappointed in the Ukrainian community because the Ukrainian language was used only for church and school, and outside of these contexts people would slip into English, even if they spoke Ukrainian. As such, Tania did not feel any connection to the Ukrainian community in Saskatoon. She thinks the Ukrainian language is treated as if it were "superficial," and does not feel that the way it is used in Saskatoon is meaningful in terms of identity. Tania and her husband did not make their children go to Ukrainian school in Saskatoon, but they did send them to Ukrainian Saturday school when they lived in Ontario. It is important to Tania that her children know the Ukrainian language, but she would rather teach them at home.

At the time of the interview, Olena was in her fifties. She grew up in Edmonton and then moved to Saskatoon. Olena was a child of immigrant parents who were displaced persons (DPs) and grew up "speaking Ukrainian as a law in their house." Ukrainian was required by her parents in the home and in the public sphere. Olena grew up in a multicultural neighbourhood, but beyond having one Polish friend she was almost exclusively friends with children of Ukrainian DPs outside of school. Her extracurricular life was exclusively Ukrainian. Olena attended Ukrainian school twice a week and was involved with Plast. ${ }^{6}$ She felt that the extent of her community involvement was limiting. Olena and the children of other DPs were expected to "carry the torch for this poor country," Ukraine, and she was brought up with the expectation and demand that she support "Ukraina," and hate Russians. She feels that it was destructive to have been born with hatred. However, while Olena has a negative attitude toward the Ukrainian community, she has a positive attitude toward the Ukrainian language.

\footnotetext{
${ }^{6}$ Plast is a Ukrainian organization, similar to boy scouts, but not exclusive in gender.
} 
Orest was estimated to be in his mid-sixties at the time of the interview. He was born in Saskatoon. His parents were very involved in the Ukrainian community when he was a child, and he spoke Ukrainian exclusively in the home until the age of 7 or 8 . When Orest moved to eastern Canada, he hardly ever spoke Ukrainian, and was not very active in the community. He eventually moved back to Saskatoon, and over the last 10-15 years he has become more involved with the Ukrainian community. Orest travels to Ukraine for his work and is involved informally with the Ukrainian Canadian Congress. Since he started travelling regularly to Ukraine and has been involved in the Ukrainian community, Orest has started to speak Ukrainian again.

\section{LANGUAGE ATTITUDE AND COMMUNITY PARTICIPATION}

To reiterate, the data we analyze here comes from oral history interviews in which the respondents were not asked directly about their attitude toward the Ukrainian language. Respondents were given the freedom to explore whatever topics were important to their lives; however, our analysis of the data concerned only the Ukrainian language. Thus, here we provide our reading and interpretation of the interview data to determine respondents' language attitudes. Using respondents' views about (a) the importance of the Ukrainian language in their lives and (b) language continuity, in the context of passing the language on to future generations, we inferred their attitudes toward the Ukrainian language. Most respondents did not plainly state that they saw the Ukrainian language in a positive or negative light. Rather, they discussed whether or how knowing Ukrainian had impacted them, whether they wished they knew Ukrainian better, and whether they had passed the Ukrainian language on to their children. Some respondents did not think the Ukrainian language was important; some respondents did not think the Ukrainian language had benefits for people in Canadian society. Table 1 shows a correlation between the person's ability and predisposition to use the Ukrainian language and the person's attitude toward the Ukrainian language.

As evidenced by the ten ethnographic cases presented above, we conclude that active participation in organized community life can lead to increased use of the Ukrainian language and a positive attitude toward the Ukrainian language (Table 1). As language is practised and used in social contexts, it became obvious very early in our analysis that in order to evaluate the use of the Ukrainian language in an "active way" we also needed to pay attention to respondents' participation in Ukrainian community life and events. We needed to arrive at some classification of this participation. Aware of the positivist nature of any classification, we nonetheless 
differentiated between active and non-active community participation. Under "active Ukrainian community participation" we mean regular, ongoing involvement with formal Ukrainian community organizations and under "non-active" participation we mean infrequent, irregular participation in one or two events in the organized Ukrainian community per year, and non-involvement, for the most part, in structured Ukrainian community life. This differentiation follows the Ukrainian Canadians' own casual understandings of how members of the Ukrainian community participate or do not participate in the life of the Ukrainian community. For anthropological analysis, this emic perspective, that is a viewpoint of the subject, counts.

Difficulty also arose when classifying respondents as either active or non-active, because the respondents had varying levels of participation in the Ukrainian community throughout their lifetimes. Within the researched ten interviews, for a number of respondents, instead of classifying them in only one category, we have noted that their community participation level changed over time, and where possible we commented on how this change has affected Ukrainian language usage and the respondent's attitude toward the Ukrainian language. Another issue that arose when we tried to classify Ukrainian community participation was whether to classify participation in the church as active participation in the organized Ukrainian community. Those who attended church occasionally or semi-regularly with no participation beyond liturgy were classified as non-active, while those who were involved in activities beyond liturgy were classified as active. These activities included Sunday school, catechism, women's and men's associations, and church boards. For the most part, classification was based on our own judgments, and we note that different researchers could have classified some individuals differently.

Participation in community life appeared to have direct impact on the language attitude of the respondent. Several respondents reported wanting to learn the Ukrainian language or wanting their children to learn the Ukrainian language after becoming involved with the Ukrainian community. John's interview illustrates this well. As a child, John used the Ukrainian language on a daily basis, while also being involved in the community. He then moved away and stopped using the Ukrainian language. When John moved back to the prairies and found himself involved with the Ukrainian community again, he found that he had more opportunities to use Ukrainian and started to use the language again. Mary decided to learn Ukrainian as a result of her involvement with a Ukrainian dance group. Elizabeth was never involved in the Ukrainian community and did not feel that her Ukrainian identity or Ukrainian language was important, despite the fact that she once took a Ukrainian language class. 
As a linguistic anthropologist, Laura Ahearn observed, within Spanish speaking communities in the United States, when ethnic minorities pursue their lives within the organized ethnic communities, they have an opportunity to retain their language longer (125). We suggest that Ukrainian language use in Canada follows the same pattern. Thus, participation in the Ukrainian community can influence both Ukrainian language use and the attitude toward the Ukrainian language. Ukrainian community organizations not only provide an outlet for the use of the Ukrainian language, they also provide a social venue for members to use the Ukrainian language.

\section{LANGUAGE USE, FROM HABITUAL TO PERFORMATIVE}

The answers to the questions pointed to an interesting pattern that we claim is characteristic of the field of Ukrainian language use in the Western Canadian context. When Tania moved to Western Canada from her home in Ontario, she stumbled on a very different language community than the one she was used to in eastern Canada.

Researcher: How was the move to here for you ...?

Tania: We moved here six years ago, to Saskatoon, and well . . . [my husband] was offered this position in Saskatchewan that was really attractive .... It was a two-year contract and that's what made me agree to come. If it was bad after one year, then we would move back .... It was only going to be temporary ... moving out to Saskatchewan gave us the promise of something more of a home life ... there was the hope that we could be together a bit more.... Two years has become, well we are starting on our seventh year at the beginning of the summer.... We have had more of home life, but in terms of the Ukrainian community, we had hoped that our move from southern Ontario to Saskatoon would be an opportunity to really be involved more in the Ukrainian community, because I knew this is where our people were the pioneers here, and I had this conception of the west as being the namesake of Ukrainian Canadians, but I found that there was very little Ukrainian language outside of a formal use of it. In the Ukrainian school they taught Ukrainian, at church Ukrainian was used, but just amongst people, even if they were Ukrainian speaking, we would slip into English, because people were used to speaking English. I mean, understandable, now that I'm living here I understand that, but I was shocked and disappointed .... We didn't feel any connection [...] to the Ukrainian community .... I have this impression of the Ukrainian that is left as being extremely superficial. Everyone does Ukrainian dancing and knows how to write pysanky, but I don't get the feeling that it is very meaningful in terms of identity, or way of living .... There's an emptiness to it in my experience here, that makes me really sad actually. 
Tania's experience was echoed in some other interviews recorded for the oral history project, and together they point to an existing gap in how Ukrainian is practised in some Ukrainian communities in Canada. The field of linguistic anthropology has found that communities that consist of more recent immigrants may continue to use the mother tongue in habitual, practical, familiar ways (Ahearn 125). In these communities, the language serves its users pragmatically. At the same time, in old, "established" ethnic groups, this pragmatic use of language can be supplemented or even substituted by the symbolic use of language. This symbolic use of language is characterized in anthropological literature as ideological (Fishman 228) or as performative (Duranti 380-81). In all cases, at stake is the fact that language in these communities gained a value other than a practical value. Use of the language becomes a matter of identity maintenance, politics, and ideology. Knowing the language or knowing some of it enhances the language user's sense of identity.

This symbolic use of the Ukrainian language is documented both within the interview setting and outside of it. In our sample of ten interviews, respondents spoke English during the interview, and that appeared to be the language of their daily interactions. However, patterns of bilingualism, such as ethnic term retention (for example, always using the word "baba" for grandmother), and code-switching (alternating English and Ukrainian in a conversation), coupled with their performative application in the interview, were at play. The language usage of the respondents studied here illustrates the ways in which "established," and mostly English-speaking Ukrainian Canadians, use the Ukrainian language in their interactions with the members of their ethnic communities.

The very nature of the oral history research project conducted in 2002 provided the respondents with an opportunity to openly "manifest" their relationship with, if not their knowledge of, the Ukrainian language. Thus, the project design invited participants to perform their Ukrainianness for the researchers, through the language used in the interview. Common Ukrainian terms such as traditional Ukrainian food, i. e., "perogies," "kubassa," "nalysnyky," or kin terminology, such as "baba," "d/gido," "cholovik," "zhinka," were commonly used during the interview, perhaps as they would be used in respondents' everyday life. Other stock phrases, expressions, and sayings, such as greetings, holiday terms, and short comprehension phrases may have been used performatively to demonstrate the connection between the speakers and the researchers, who were themselves of Ukrainian background.

Referencing "outside of the interview" situations, the respondents provided much evidence of how the Ukrainian language is used symbolically in their immediate Ukrainian Canadian settings. Tania's story, cited above, provides insight into the dominance of symbolic language use over practical 
use. Tania referred to symbolic language use as "formal" use. Such use is routinely involved in Ukrainian greetings and farewell phrases-short references and stock phrases of relevance utilized in a given speech or community event, suggesting the symbolic rather than practical use of language.

The interviews also provided evidence of ideological implications of Ukrainian language usage. For example, Nadia discussed the issue of language in the church. Her parents chose to switch from the Ukrainian Catholic Church to the Ukrainian Orthodox Church because there was not enough English being spoken at the Catholic church. Nadia chose to stay with the Catholic church, while her immediate family members joined the Ukrainian Orthodox Church. This particular story touches on a deep rift within religious Ukrainian Canadian communities with respect to language use in the church, that is, whether the church should continue to use Ukrainian or should switch to English, the more widely understood language. This further illustrates the new ideological interpretations of the relationships between Ukrainian Canadians, the Ukrainian Canadian identity, and the Ukrainian language.

Some respondents commented on the importance of passing the Ukrainian language on to their children (ideological use). Those for whom learning the Ukrainian language was important were considered to have positive attitudes. Several respondents implicitly understood that one would never master the Ukrainian language. Ultimately, the complete mastery of the Ukrainian language was not as important to respondents as the fact that they were engaged in mastering it. Thus, the emphasis is on maintaining and displaying the relationship between oneself and the language and not on full mastery of the language.

\section{CONCLUSIONS}

We analyzed ethnolinguistic data from the 2002 oral history project that examined socio-cultural change among Ukrainians on the Canadian prairies. Our purpose was to study individual Ukrainian Canadians' perspectives on language use within established, "old" networks of the Ukrainian Canadian community in Western Canada. As the oral history project was conducted early in the twenty-first century, the data enabled us to examine use of the Ukrainian language and the attitude toward the Ukrainian language of individual Ukrainian Canadians before (a) the explosion of communication technologies and electronic social media and (b) a steady immigration wave of Ukrainians from Ukraine to the Canadian prairies, in particular to 
Saskatchewan, under the umbrella of the provincial immigration program. ${ }^{7}$ Within the time frame of the examined life stories documented in 2002-03, the linguistic data and interviews' content suggested a strong correlation between Ukrainian language use, attitude toward the Ukrainian language, and community participation among Ukrainian Canadians on the prairies. Thus, active involvement in Ukrainian community life and community affairs and participation in Ukrainian organizations tended to inform a positive attitude toward the Ukrainian language, usually reflected in the person's desire to use it, to study it, and to pass it on to the next generation. Our data suggest that a strong positive attitude toward the Ukrainian language often translated into an actively maintained engagement with that language, but not necessarily with the complete knowledge and mastery of it. Thus, we can propose that this engagement with the language pursued by the language users is an important aspect of who they are as Ukrainians in Canada.

We provide ethnographic and ethnolinguistic data regarding the use of the Ukrainian language on the Canadian prairies. Use of the Ukrainian language in Western Canada unfolded within two domains of cultural practice, habitual and performative. Correspondingly, two modes of language use are in play in Ukrainian Canadian communities, practical/pragmatic and symbolic/ideological, with the latter oftentimes dominating, especially in the context of organized Ukrainian community events.

Though we can speak affirmatively only about the interviews recorded for the project, we anticipate that Ukrainian Canadians in other contexts outside of the Canadian prairies may behave linguistically in ways similar to those of the project respondents, participating in both practical/pragmatic and symbolic/ideological language practices. Our findings can be of use to speakers of the Ukrainian language coming into such communities from afar (be they from ethnic networks in other parts of the country, recent immigrants, or visitors from Ukraine), who could be cross-culturally unprepared to face this dual nature of language use on the Canadian prairies.

7 The Government of Saskatchewan introduced its own Immigration Nominee Program (SINP) in 2003 (McGrane 62). 


\section{Works Cited}

Ahearn, Laura M. Living Language: An Introduction to Linguistic Anthropology. WileyBlackwell, 2012.

Atkinson, Robert. The Life Story Interview. Sage, 1998.

Bociurkiw, Bohdan. "The Federal Policy of Multiculturalism and the Ukrainian Canadian Community." Ukrainian Canadians: Multiculturalism, and Separatism: An Assessment, edited by Manoly R. Lupul, Canadian Institute of Ukrainian Studies, 1978, pp. 99-128.

Donna. Interview by Anastasia Tataryn. Sociocultural Change amongst the Ukrainian Canadians on the Prairies: Oral History Project (2002-03). Saskatoon Centre for the Study of Ukrainian Heritage, 16 July 2002.

Duranti, Alessandro. A Companion to Linguistic Anthropology. Blackwell Publishing, 2004.

Elizabeth. Interview by Anastasia Tataryn. Sociocultural Change amongst the Ukrainian Canadians on the Prairies: Oral History Project (2002-03). Saskatoon Prairie Centre for the Study of Ukrainian Heritage, 2 Aug. 2002.

Fishman, Joshua A. "The Third Century of Non-English Language Maintenance and Non-Anglo Ethnic Maintenance in the United States of America." TESOL (Teachers of English to Speakers of Other Languages) Quarterly, vol. 7, no. 3, 1973, pp. 221-33.

Foley, William. Anthropological Linguistics: An Introduction. Blackwell Publishers, 1997.

John. Interview by Angela Wojcichowsky. Sociocultural Change amongst the Ukrainian Canadians on the Prairies: Oral History Project (2002-03). Saskatoon Prairie Centre for the Study of Ukrainian Heritage, 15 Aug. 2002.

Khanenko-Friesen, Natalia, and Theresa Zolner, project co-ordinators. Sociocultural Change amongst the Ukrainian Canadians on the Prairies: Oral History Project (2002-03). Saskatoon Prairie Centre for the Study of Ukrainian Heritage, 2002.

Leo. Interview by Theresa Zolner. Sociocultural Change amongst the Ukrainian Canadians on the Prairies: Oral History Project (2002-03). Saskatoon Prairie Centre for the Study of Ukrainian Heritage, 4 July 2002.

Lupul, Manoly R. "Ukrainian-Language Education in Canada's Public Schools." A Heritage in Transition: Essays in the History of Ukrainians in Canada, edited by Manoly R. Lupul, Minister of Supply and Services Canada, 1982, pp. 215-43.

Marunchak, M. H. The Ukrainian Canadians: A History. Friesen Printers, 1982.

Mary. Interview by Anastasia Tataryn. Sociocultural Change amongst the Ukrainian Canadians on the Prairies: Oral History Project (2002-03). Saskatoon Prairie Centre for the Study of Ukrainian Heritage, 9 Aug. 2002.

McGrane, David. New Directions in Saskatchewan Public Policy. U of Regina P, 2011.

Nadia. Interview by Angela Wojcichowsky. Sociocultural Change amongst the Ukrainian Canadians on the Prairies: Oral History Project (2002-03). Saskatoon Prairie Centre for the Study of Ukrainian Heritage, 7 July 2002.

Olena. Interview by Anastasia Tataryn. Sociocultural Change amongst the Ukrainian Canadians on the Prairies: Oral History Project (2002-03). Saskatoon Prairie Centre for the Study of Ukrainian Heritage, 7 June 2002. 
Ol'ha. Interview by Angela Wojcichowsky. Sociocultural Change amongst the Ukrainian Canadians on the Prairies: Oral History Project (2002-03). Saskatoon Prairie Centre for the Study of Ukrainian Heritage, 18 June 2002.

Orest. Interview by Angela Wojcichowsky. Sociocultural Change amongst the Ukrainian Canadians on the Prairies: Oral History Project (2002-03). Saskatoon Prairie Centre for the Study of Ukrainian Heritage, 25 July 2002.

Statistics Canada. "2006 Census Topic-based Tabulations." Statistics Canada. https://www12.statcan.gc.ca/census-recensement/2006/dp-pd/tbt/Rpeng.cfm?LANG $=\mathrm{E} \& A P A T H=3 \& D E T A I L=1 \& D I M=0 \& F L=A \& F R E E=1 \& G C=0 \& G I D=$ $0 \& \mathrm{GK}=0 \& \mathrm{GRP}=1 \& \mathrm{PID}=89189 \& \mathrm{PRID}=0 \& \mathrm{PTYPE}=88971 \& \mathrm{~S}=0 \&$ SHOWALL $=$ No\& $\underline{\text { SUB }=0 \& \text { Temporal }=2006 \& \text { THEME }=70 \& V I D=0 \& V N A M E E=\& V N A M E F}$. Accessed 14 June 2018.

Statistics Canada. "Ethnic and Cultural Origins of Canadians: Portrait of a Rich Heritage." Statistics Canada, 25 Oct. 2017. https://www12.statcan.gc.ca/censusrecensement/2016/as-sa/98-200-x/2016016/98-200-x2016016-eng.cfm. Accessed 14 June 2018.

Swyripa, Frances. "Ukrainian Canadians." The Canadian Encyclopedia, 4 Apr. 2012. https://www.thecanadianencyclopedia.ca/en/article/ukrainian-canadians. Accessed 14 June 2018.

Tania. Interview by Natalia Shostak. Sociocultural Change amongst the Ukrainian Canadians on the Prairies: Oral History Project (2002-03). Saskatoon Prairie Centre for the Study of Ukrainian Heritage, 30 July 2002. 